\title{
Influence of biological and management factors on piglets in the maternity phase
}

\author{
Influência de fatores biológicos e de manejo sobre o leitão na fase de maternidade
}

Cristina Satie Hideshima ${ }^{1 *}(D)$, Geraldo Camilo Alberton ${ }^{2}$ (D) , Sergio Rodrigo

Fernandes $^{1}$ (D) , Daiane Güllich Donin ${ }^{2}$ (D) , Ray Nascimento Gonsalves ${ }^{2}$ (D), Ana Paula Backes $^{2}$ (D) , Félix Daniel Martins Mentges ${ }^{2}$ (D) , Alex Junior dos Santos Silva² (D), Altair Silveira de Farias Júnior ${ }^{2}$ (D)

'Universidade Estadual de Londrina (UEL), Londrina, Paraná, Brazil

'Universidade Federal do Paraná (UFPR), Palotina, Paraná, Brazil

*Correspondent - cristinahideshima@gmail.com

Received

January 19, 2021.

Accepted

May 3, 2021

Published

July 28, 2021.

www.revistas.ufg.br/vet

visit the website to get the

how to cite in the article page.

\begin{abstract}
The goal of this study was to assess the effects of uniformization management, birth order (BO), birth weight (BiW) and their interactions on the performance of piglets in the maternity phase. Sows $(n=25)$ and their litters $(n=$ 388 piglets) were distributed into two treatments, namely: UNIF - uniformization of piglets between different litters right after birth; and BIOM - piglets kept up to 12 hours after birth with their biological mothers. In both treatments, the effect of BO was assessed in three groups characterised by BO of $1-6,7-12$, and $\geq 13$. The effect of BiW was assessed in four groups defined as 'very light', 'light', 'medium', and 'heavy'. The design was completely randomised in a $2 \times 3 \times 4$ factorial scheme, totalling 24 treatments with 16 piglets/treatment, on average. Weight gain from birth to 72 hours after birth $\left(W_{72 h}\right)$ was greater in the BIOM treatment. The colostrum intake $(\mathrm{Cl})$ was lower in piglets with $\mathrm{BO} \geq 13$. In general, piglet performance increased in response to the increase in BiW. There was interaction between uniformization management and BiW with respect to $\mathrm{Cl}$ related to body weight $\left(\mathrm{Cl}_{\mathrm{BW}}\right)$, which was greater in very light piglets in the UNIF treatment $(27.48 \%$ $\mathrm{BW})$, and lower in heavy piglets in the BIOM treatment $(16.82 \%$ BW). It was possible to obtain satisfactory piglet performance by keeping the litters with their biological mothers until 12 hours after birth. The $\mathrm{Cl}$ expressed on an absolute basis ( $g$ ) was greater; however, $\mathrm{Cl}$ expressed on relative basis with respect to body weight (\% BW) was lower in heavy piglets.
\end{abstract}

Keywords: birth weight, colostrum, hyperprolificity, pig farming, uniformization management, weaning

\section{Resumo}

O objetivo deste trabalho foi avaliar os efeitos de manejo de uniformização, ordem de nascimento $(\mathrm{ON})$, peso ao nascimento (PN) e suas interações no desempenho de leitões na fase de maternidade. Porcas $(n=25)$ e suas leitegadas ( $n=388$ leitões) foram distribuídas em dois tratamentos: 
UNIF - uniformização de leitões entre leitegadas distintas logo após o nascimento; $\mathrm{MBIO}$ - leitões mantidos até 12 horas pós-parto com a mãe biológica. Nos dois tratamentos o efeito da ON foi avaliado em três grupos caracterizados pela ON de 1-6, 7-12 e $\geq 13$; o efeito de PN foi avaliado em quatro grupos definidos como Muito leve, Leve, Médio e Pesado. 0 delineamento foi inteiramente casualizado em esquema fatorial $2 \times 3 \times$ 4, totalizando 24 tratamentos com 16 leitões/tratamento, em média. 0 ganho de peso do nascimento até 72 horas de vida $\left(\mathrm{GP}_{72 \mathrm{~h}}\right)$ foi maior em $\mathrm{MBIO}$. A quantidade de colostro ingerida $(\mathrm{QCl})$ foi menor em leitões de $\mathrm{ON} \geq 13$. Em geral, o desempenho dos leitões aumentou em resposta ao aumento do PN. Houve interação entre manejo de uniformização e PN para $\mathrm{QCl}$ em relação ao peso corporal $\left(\mathrm{QCl}_{\mathrm{PC}}\right)$, que foi maior em leitões Muito leves em UNIF (27,48\% PC) e menor em leitões Pesados em MBIO $(16,82 \%$ PC). É possível obter bom desempenho de leitões mantendo a leitegada com a mãe biológica até 12 horas pós-parto. A quantidade de colostro ingerida em base absoluta ( $\mathrm{g}$ ) é maior, mas relativa ao peso corporal (\% PC) é menor em leitões pesados.

Palavras-chave: colostro; desmame; hiperprolificidade; manejo de uniformização; peso ao nascimento; suinocultura.

\section{Introduction}

The intense genetic improvement and the improvement of hyperprolific strains have caused an increase in the number of piglets born per sow. However, some characteristics, such as uterine capacity, placental efficiency, and number of teats, have not been improved to the same extent. Thus, foetal development is impaired, leading to decreased birth weight (BiW) and increased weight variability in newborn piglets, affecting their performance in the maternity phase ${ }^{(1-3)}$.

Neonatal mortality is one of the main causes of losses in the lactation period, and the most critical moment is during the first 24 hours of the piglets' lives ${ }^{(4)}$. Piglets with low Biw have lower chances of survival and lower performance until slaughter ${ }^{(5,6)}$. According to Kilbride et al. ${ }^{(7)}, 84 \%$ of pre-weaning mortality occurs in the first week of life of the piglets, with $28 \%$ of these deaths occurring during the first 24 hours. Low viability at birth, starvation, crushing of sick piglets, and diarrhoea are among the main causes of death in the maternity pen, representing $13.8,6.8,4.7$, and 3.5\% of mortality, respectively ${ }^{(6,7)}$. Failure to ingest or the consumption of insufficient amounts of colostrum lead to starvation and predispose piglets to hypothermia, crushing, and diarrhoea. Thus, adequate colostrum intake reduces deaths in the maternity pen and losses in the production system.

Colostrum provides passive immunity, which is necessary for the protection of the piglets ${ }^{(8)}$. It also provides growth factors that stimulate intestinal development and maturation(9). Immunoglobulin $G(\operatorname{lgG})$ is found in greater amount among the immunoglobulins present in colostrum, representing about $75 \%$ of the total number ${ }^{(10)}$. However, the amount of IgG in colostrum rapidly decreases in the first 24 hours after 
birth. This fact indicates that the piglets should ingest colostrum soon after birth, so that they are not exposed to the environmental microbiota for too long without proper protection. According to Devillers et al.(11), the ingestion of $200 \mathrm{~g}$ of colostrum within 24 hours after birth is the minimum amount required for providing passive immunity, reducing the risk of death before weaning, and allowing satisfactory piglet growth. Quesnel et al. ${ }^{(4)}$ stated that the intake of approximately $180 \mathrm{~g}$ of colostrum $/ \mathrm{kg}$ body weight is necessary to provide sufficient energy and immunoglobulins, thus ensuring piglets' survival. This way, there is controversy regarding the amount of colostrum to be ingested in order to ensure survival and promote good piglet performance.

Colostrum intake contributes to the thermoregulation process of the body through energy supply. Therefore, the faster the piglet suckles after birth, the better its ability to maintain thermal homeostasis. However, piglets with low BiW have lower energy reserves and take longer to perform the first feeding, which leads to increased sensitivity to cold ${ }^{(12)}$. In litters with different weights, smaller piglets suffer greater damage when the litters in which they are inserted are large. This damage results from two reasons, i.e., the greater number of competitors, and the sows being old, which entails smaller number of functional teats ${ }^{(13)}$. Different management strategies are targeted at improving piglets' performance and reduce body weight variation between piglets within litters, which is mainly caused by lighter piglets ${ }^{(14)}$. This way, litters are equalised in order to reduce mortality, especially in light pigs ${ }^{(15)}$. This management is a standard procedure in the raising of piglets, which involves the relocation of piglets from their biological mothers to another litters ${ }^{(16)}$. The survival of piglets in large litters can be increased if the number of surplus piglets is equalised ${ }^{(17)}$.

Uniformization minimises body weight variations within the same litters ${ }^{(18,19)}$ and, when performed up to 48 hours after birth, does not cause a drop in the piglets' performance ${ }^{(19,20)}$. However, in practice, the uniformization of litters is often carried out on farms indiscriminately throughout lactation, causing delay in the growth of these animals. It is recommended that uniformization be carried out to a minimum extent, as it can be stressful for sows and piglets. In addition, if necessary, it should be performed as soon as possible, i.e., 12 to 24 hours after birth ${ }^{(21)}$.

Several aspects directly affect the results of uniformization, such as the moment in which this management is carried out, the size and number of piglets, and the parity order (PO) of the adoptive and the biological mothers. The transfer of piglets should preferably be carried out between 6 and 24 hours after birth, a period in which the specific teats for the piglets to absorb the maximum amount of immunoglobulin from their biological mothers' colostrum has not yet been defined. The aim is to allow the transferred piglets to take advantage of the adoptive mothers' colostrum without interfering with the transfer of passive cellular immunity ${ }^{(19-24)}$, which is only obtained through colostrum ingestion from the biological mothers(24). The performance and viability of piglets in the maternity phase is highly dependent on factors related to the adoptive and the biological sows, from colostrum quality and milk production to the conformation of the breast tract and maternal ability, which varies according to the $\mathrm{PO}^{(16,25,26)}$. 
In this context, the present study was conducted in an attempt to test four hypotheses, namely: (1) piglets submitted to uniformization management soon after birth have similar performance to that of piglets that remain up to 12 hours after birth with their biological mothers; (2) piglets that are born first perform better than those that are born last in the litter; (3) piglets that are born heavier perform better than piglets that are born lighter; and (4) there is an interaction between these factors influencing the performance of piglets in the maternity pen. Thus, the goal of the present study was to assess the effects of uniformization management, BO, and BiW, as well as their interactions influencing the performance of piglets during the maternity phase.

\section{Material and methods}

The present study was approved by the Ethics Committee on the Use of Animals, at the Universidade Federal do Paraná (CEUA/UFPR), under Protocol No. 41/2017, which certified that this research was in accordance with the Ethical Principles of Animal Experimentation, established by the National Council for the Control of Animal Experimentation (CONCEA).

The research was conducted in a commercial pig farm that produced piglets with 1,100 sows, located in Palotina, western region of the State of Paraná, Brazil. Piglets ( $\mathrm{n}=$ 388) originating from DanBred sows (DB90) $(n=25)$ were assessed being followedup from birth to weaning. Sows of PO 1 to 7 that had litters with an average of 16 piglets (range 8 to 22 piglets/litter) were used in the study. The sows were transferred to the maternity pen 3 to 4 days before the expected farrowing date (EFD = 114 days) and were housed in cells previously washed and disinfected. The cells had individual creeps heated with 100-watt electric lamps. In the week of birth, rubber mats and wood shavings were placed on the floor of the creeps. After farrowing, the sows received no feed. The following day, they were fed a lactation diet (18.5\% crude protein; $1.0 \%$ lysine, and $3400 \mathrm{kcal}$ metabolisable energy, based on dry matter). The amount of feed provided was increased by $1 \mathrm{~kg} /$ day, starting with $1 \mathrm{~kg} /$ day the day after birth until reaching the amount of $2 \mathrm{~kg} / \mathrm{sow}+0.400 \mathrm{~kg}$ for each piglet in the litter, which was provided in four meals a day throughout lactation. Water was provided ad libitum to sows and piglets. All farrows were induced, except for primiparous sows. To that end, 24 hours before EFD, 0.7 to $1.0 \mathrm{~mL}$ of synthetic analogue of PGF2a (cloprostenol sodium - Sincrosin ${ }^{\circledR}$ ) were intramuscularly administered. All births were assisted, with the start and end times being recorded for each one. The final time of farrow was determined by placenta expulsion or after the application of 0.5 to $1.0 \mathrm{~mL}$ of intravenous oxytocin (auricular vein), as well as by touching and confirming that there were no more piglets. Placental membranes were removed from the piglets when they were born surrounded by them, and, when necessary, the piglets were resuscitated. At birth, the piglets were dried with paper towels, placed in a container with wood shavings, and then placed in another container with drying powder. Then, the umbilical cords were cut, asepsis was performed with iodine, and the piglets were individually weighed on a digital scale (precision of $1 \mathrm{~g}$ ). At the end of the postnatal management, the piglets returned to their biological mothers, being allowed to suckle until the uniformization management was 
performed.

The effects of three factors on the piglets' performance in the maternity pen were assessed, namely: (1) uniformization management; (2) BO; and (3) BiW. The effect of uniformization management was assessed using two treatments: UNIF - uniformization of piglets between different litters right after birth; and BIOM - piglets kept up to 12 hours after birth with their biological mothers. The effect of BO was assessed in three groups characterised by BO from 1 to 6,7 to 12, and equal to or greater than 13. Finally, the effect of BiW was assessed by establishing four groups with distinct BiW ranges, named 'very light', 'light', 'medium', and 'heavy'. These groups were defined based on the standard deviations (SD) of the piglets' BiW (Table 1). The experimental design was completely randomised in a $2 \times 3 \times 4$ factorial scheme, totalling 24 treatments. The replications consisted of the piglets grouped within each treatment, and the number of replicates was uneven between treatments. The average of replications was 16 piglets per treatment, with a variation from 7 to 26 piglets per treatment.

Table 1. Criteria established for each factor assessed and number of piglets per treatment or group assigned to each independent factor.

\begin{tabular}{|c|c|c|c|c|}
\hline Factor & $\begin{array}{l}\text { Treatment/ } \\
\text { Group }\end{array}$ & Criterion' & $\begin{array}{c}\text { Weight } \\
\text { range } \\
\text { (g) }\end{array}$ & $\begin{array}{l}\text { Piglets } \\
\text { (n) }\end{array}$ \\
\hline \multirow{2}{*}{$\begin{array}{l}\text { Uniformization } \\
\text { management }\end{array}$} & UNIF & $\begin{array}{l}\text { Uniformization of different litters } \\
\text { just after birth. }\end{array}$ & & 182 \\
\hline & $\mathrm{BIOM}$ & $\begin{array}{l}\text { Remaining with the biological } \\
\text { mothers up to } 12 \text { hours after birth. }\end{array}$ & & 206 \\
\hline \multirow{3}{*}{ Birth order } & $1-6$ & Birth order $=1$ to 6 & & 150 \\
\hline & $7-12$ & Birth order $=7$ to 12 & & 144 \\
\hline & $\geq 13$ & Birth order $=>13$ & & 94 \\
\hline \multirow{4}{*}{ Birth weight } & Very light & $\mathrm{BiW} \leq \mathrm{BiW}_{M}-0.66 * \mathrm{SD}_{\mathrm{BiW}}$ & $\leq 1096$ & 108 \\
\hline & Light & $\mathrm{BiW}_{\mathrm{M}}-0.66 * \mathrm{SD}_{\mathrm{BiW}}<\mathrm{BiW} \leq \mathrm{BiW}_{\mathrm{M}}$ & $\begin{array}{l}1097 \text { to } \\
1329\end{array}$ & 78 \\
\hline & Medium & $\mathrm{BiW}_{M}<\mathrm{BiW} \leq \mathrm{BiW}_{M}+0.66 * \mathrm{SD}_{\text {BiW }}$ & $\begin{array}{l}1330 \text { to } \\
1563\end{array}$ & 102 \\
\hline & Heavy & $\mathrm{BiW}>\mathrm{BiW}_{\mathrm{M}}+0.66 * \mathrm{SD}_{\mathrm{BiW}}$ & $>1564$ & 100 \\
\hline
\end{tabular}

Note. BiW = birth weight; $\mathrm{BiW}_{\mathrm{M}}=$ mean birth weight; $\mathrm{SD}_{\mathrm{BiW}}=$ standard deviation for birth weight.

In order to assess uniformization management, the sows were evenly distributed according to PO within each treatment defined for this factor (Table 1). In the UNIF 
treatment, the piglets received coloured ear tags (green, red, and blue) with sequential numbering, and remained with their biological mothers until the end of farrowing. Soon after, they went through uniformization management, keeping on average one piglet per available teat, and other routine managements performed on the farm (wear of teeth, tail docking, iron injection, and ear tagging). In the BIOM treatment, piglets received only sequentially numbered yellow ear tags, and remained with their biological mothers for the first 12 hours after birth, not suffering any kind of interference during this period, regardless of the number of piglets born. The piglets were routinely managed on the farm (the same previously described in the UNIF treatment) 12 hours after birth, and those that exceeded the number of available teats were transferred to other sows.

To assess performance in the maternity phase, piglets were weighed after 24 (W24h) and 72 hours (W72h) after birth and at weaning (WW), which occurred at 21 days of age. The difference between these weights and BiW represented weight gain obtained after 24 and 72 hours $\left(W_{24 h}\right.$ and $W_{72 h}$ ) and at weaning $\left(W_{W}\right)$. The occurrence of deaths of piglets was recorded to calculate the mortality rate (MR) in the maternity phase. The transfer of piglets between litters was also duly registered during the experimental period.

The colostrum intake $(\mathrm{Cl}, \mathrm{g})$ was estimated as proposed by Devillers et al. ${ }^{(26)}$ using the following equation:

$$
\mathrm{CI}=-21.4+0.217 \mathrm{t}+1861019 \frac{\mathrm{W} 24 \mathrm{~h}}{\mathrm{t}}+\mathrm{BiW}\left(54.80-\frac{1861019}{\mathrm{t}}\right) \times\left(0.9985-3.7 \times 10^{-4} \times \mathrm{t}_{\mathrm{FS}}+6.1 \times 10^{-7} \times \mathrm{t}^{2}{ }_{\mathrm{FS}}\right)
$$

where: BiW = birth weight $(g) ;$ W24h = weight 24 hours after birth $(g) ; t=$ time from birth to weighing after 24 hours (min); $t_{F S}=$ mean of the interval between birth and first suckling (min). The $t_{F S}$ was estimated at 30 min, according to Devillers et al. ${ }^{(26)}$

The $\mathrm{Cl}$ was also expressed on a proportional basis with respect to the piglets $\mathrm{BW}\left(\mathrm{Cl}_{\mathrm{BW}}\right)$, using the following formula:

$\mathrm{Cl}_{\mathrm{BW}}=(\mathrm{Cl} / \mathrm{BiW}) \times 100$

where: $\mathrm{Cl}=$ colostrum intake $(\mathrm{g})$; BiW = birth weight $(\mathrm{g})$.

Statistical analyses were performed using the Statistical Analysis System (SAS), version $9.0^{(28)}$. Initially, the data were tested for normality by Shapiro-Wilk test (PROC UNIVARIATE), which indicated that only the MR did not fit the normal distribution.

The variables with normal distribution were assessed using a mixed model (PROC MIXED), in which the uniformization management, the BO group, the BiW group and their interactions were the fixed effects. PO and litter size (LS) were included as covariates, and the residual was randomised. Covariates were kept in the model when they had significant effects on the dependent variables. When the fixed effects and their interactions were significant, the means were compared using Tukey-Kramer test (LSMEANS function of PROC MIXED).

MR was assessed only with respect to the independent effects of the factors assessed using non-parametric tests (PROC NPAR1WAY). Thus, the treatments for uniformization 
management were compared using the Mann-Whitney test, whereas the $\mathrm{BO}$ and $\mathrm{BiW}$ groups were compared using the Kruskal-Wallis test. Probability values lower than 0.05 were considered significant in all analyses performed.es performed.

\section{Results and discussion}

The assessment of the covariates PO and LS in the statistical model indicated that only LS had a significant effect $(p<0.05)$ on the variables W24h and W72h (Table 2$)$. Thus, these variables were assessed using the model containing LS as a covariate. The model without covariates was used for analysing the data of the other variables. There was an independent effect of uniformization management $(p<0.05)$ on $W_{72 h}$ (Table 2$)$, which was greater in the piglets undergoing the BIOM treatment, in comparison to those in the UNIF treatment (Table 3). There was no effect of uniformization management ( $p$ $>0.05$ ) on the other variables assessed.

The goal of the present study was to assess whether, in farms with hyperprolific sows, it would be possible to break the paradigm that litter equalisation after birth is a necessary management that cannot be changed. Thus, sows with litters with an average of 16 piglets were chosen for the study, given that this number exceeds the capacity of the mammary system. Despite this fact, the similar results of performance, as well as similar $\mathrm{Cl}$ and MR $(p>0.05)$ between treatments demonstrated that maintaining the entire litters with their biological mothers during the first 12 hours after birth did not cause negative effects both on $\mathrm{Cl}$ and $\mathrm{WG}_{72 h}$, as well as on the maternity period. It is noteworthy that, in the $\mathrm{BIOM}$ treatment, the piglets were not subjected to any managing practice in the first 12 hours of life, which indicated that there was a natural rotation between them to carry out the feedings and, thus, ingest the same amount of colostrum as the piglets of the UNIF treatment. The similar weight of biological and adopted piglets observed in the present study is in agreement with the results obtained by Neal and Irwin ${ }^{(18)}$ in piglets that had been equalised up to 48 hours after birth. On the other hand, Zhang et al. ${ }^{(17)}$ assessed the effects of uniformization at different birth weights, and observed a decrease in daily WG when uniformization management had been performed belatedly. Studies have indicated that MR did not differ between biological or adoptive piglets up to eighteen days of age ${ }^{(15)}$ and that, controversially, adoptive piglets had shorter survival at 21 and 42 days of age ${ }^{(18)}$. 


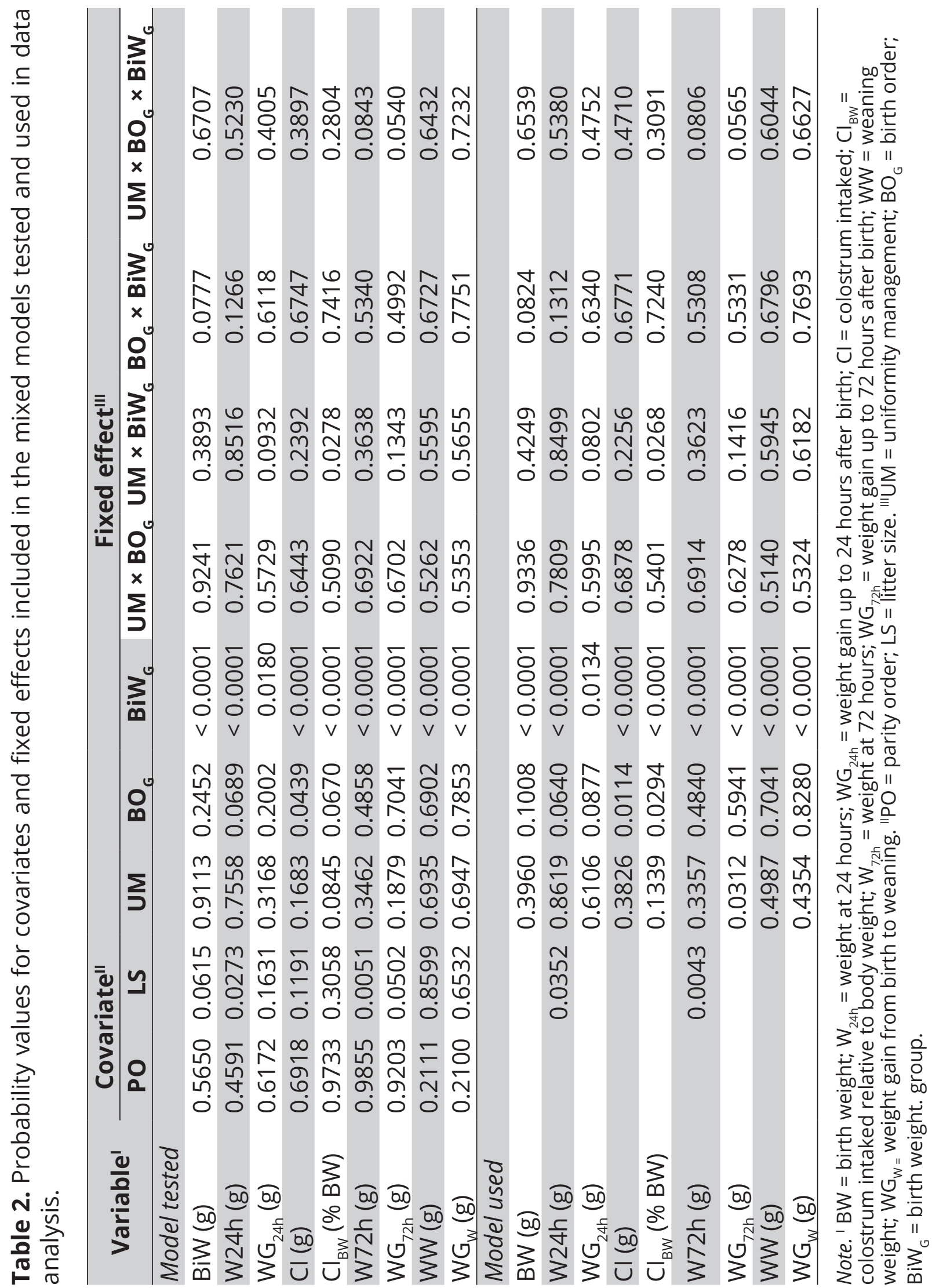


Table 3. Means and standard errors for performance traits and mortality rate of piglets in the maternity phase, in response to uniformization management.

\begin{tabular}{|c|c|c|}
\hline \multirow{2}{*}{ Variable' } & \multicolumn{2}{|c|}{ Uniformization management" } \\
\hline & UNIF & BIOM \\
\hline $\operatorname{BiW}(g)$ & $1307 \pm 25$ & $1343 \pm 26$ \\
\hline W24h (g) & $1384 \pm 27$ & $1415 \pm 27$ \\
\hline$W_{24 h}(\mathrm{~g})$ & $74 \pm 5$ & $68 \pm 6$ \\
\hline $\mathrm{Cl}(\mathrm{g})$ & $283 \pm 7$ & $276 \pm 8$ \\
\hline $\mathrm{Cl}_{\mathrm{BW}}(\% \mathrm{BW})$ & $22.39 \pm 0.58$ & $21.09 \pm 0.60$ \\
\hline W72h (g) & $1702 \pm 31$ & $1757 \pm 33$ \\
\hline$W_{72 h}(\mathrm{~g})$ & $375 \pm 13^{b}$ & $405 \pm 13^{a}$ \\
\hline WW (g) & $5668 \pm 117$ & $5573 \pm 106$ \\
\hline$W G_{w}(g)$ & $4345 \pm 103$ & $4217 \pm 90$ \\
\hline MR (\%)* & $6.59 \pm 1.84$ & $4.85 \pm 1.50$ \\
\hline
\end{tabular}

Note. 'BiW = birth weight; $\mathrm{W} 24 \mathrm{~h}=$ weight at 24 hours; $\mathrm{WG}_{24 \mathrm{~h}}=$ birth weight gain up to 24 hours after birth; $\mathrm{Cl}=$ colostrum intake; $\mathrm{Cl}_{\mathrm{BW}}=$ colostrum intake relative to body weight; $\mathrm{W} 72 \mathrm{~h}=$ weight at 72 hours; $W G_{72 h}=$ weight gain up to 72 hours after birth; WW: weaning weight; WGW = weight gain from birth to weaning; $M R=$ mortality rate. 'UNIF = uniformity between different litters; $\mathrm{BIOM}=$ permanence with the biological mother. *Assessed using the nonparametric Mann-Whitney test, with $p=0.4615$. Means followed by different lowercase letters in the same row differed by the Tukey-Kramer test $(p<0.05)$.

These results are valuable for the reality of the swine industry worldwide, since, with the emergence of hyperprolificity genetics, one of the great challenges is to ensure sufficient colostrum intake for all piglets in the litters. To that end, it is customary to equalise litters, right after birth, with the aim of keeping only one piglet per available teat in the sows. This management strategy is common on commercial farms, its purpose being the combination of sows' rearing capacity and the litter size to ensure that all piglets can have access to a functional teat ${ }^{(2)}$. Farms that implement this technique usually have satisfactory results, since the number of weaned piglets is high, with some success in the survival of light piglets. Straw et al.(19) estimated that up to $5 \%$ of piglets should be equalised to achieve this goal. However, this procedure represents management challenges and compromised transfer of maternal immunity. Therefore, other management practices involving the use of sows or artificial rearing systems should be taken into consideration ${ }^{(2)}$.

Furthermore, in general terms, the performance of these animals in the subsequent phases (nursery, growth, and finishing) is not satisfactory, which may result from the low immunological capacity of the piglets in the maternity pen. Due to sows' epitheliochorialtype placenta, newborn piglets need to acquire immunoglobulins of maternal origin by ingesting colostrum in order to obtain passive immune protection ${ }^{(8)}$. Further studies are needed to establish a possible relationship between uniformization management and occurrence of diseases in the maternity pens, including those caused by agents of the normal pigs' microbiota, such as Haemophilus parasuis, Streptococcus suis, and Mycoplasma hyosynoviae. In this context, there is a current in the health field advocating the use of health and management strategies that can reinforce the immunological capacity of piglets. The acquisition of this immunity is time dependent, as the maximum 
intestinal absorption of immunoglobulins only occurs in the first 12 hours after birth. This facts results from the progressive decrease in the newborns' intestinal permeability to colostrum immunoglobulins ${ }^{(8)}$.

Among the strategies that positively influence the immune capacity, the ingestion of colostrum (through feedings) obtained from biological mothers for at least 12 hours after birth is noteworthy, as this is the only way through which the transfer of cellular immunity occurs, in addition to transfer of antibodies ${ }^{(29)}$. Colostrum is the first secretion produced by the mammary glands during the hours immediately before farrowing. This secretion differs from milk and represents an essential vehicle for passive immunity, prebiotic compounds, and growth factors involved in intestinal development ${ }^{(30)}$. However, as previously discussed, farm workers have opposed this management scheme. There is a belief that sows, soon after farrowing, cannot keep more piglets than the number of available teats, since this situation would compromise ingestion of colostrum and increase MR resulting from crushing. The results of the present study demonstrated that this fact did not occur, since $\mathrm{Cl}, \mathrm{Cl}_{\mathrm{BW}}$, and MR were similar between the UNIF and $\mathrm{BIOM}$ methods. In addition, the latter showed better performance of piglets aged up to 72 hours of life, indicating the benefit of keeping the piglets with their biological mothers after birth.

There was an independent effect of $\mathrm{BO}(p<0.05)$ on $\mathrm{Cl}$ and $\mathrm{Cl}_{\mathrm{BW}}$ (Table 2$)$, which was greater in piglets of $\mathrm{BO} 1-6$ in comparison to pigs of $\mathrm{BO} \geq 13$ (Table 4). The piglets of BO 7-12 were similar $(p>0.05)$ to those of the other groups for $\mathrm{Cl}$ and $\mathrm{Cl}_{\mathrm{BW}}$. The other variables were not influenced $(p>0.05)$ by BO. Despite having ingested less colostrum, the performance of piglets with $\mathrm{BO} \geq 13$ was similar to that of the other $\mathrm{BO}$ groups, from 72 hours after birth until weaning.

Table 4. Means and standard errors for performance traits and mortality rate of piglets in the birth order groups during the maternity phase.

\begin{tabular}{|c|c|c|c|}
\hline \multirow{2}{*}{ Variable' } & \multicolumn{3}{|c|}{ Birth order } \\
\hline & $1-6$ & $7-12$ & $\geq 13$ \\
\hline $\mathrm{BiW}(\mathrm{g})$ & $1338 \pm 31$ & $1313 \pm 30$ & $1328 \pm 32$ \\
\hline W24h (g) & $1421 \pm 32$ & $1385 \pm 32$ & $1392 \pm 34$ \\
\hline$W_{24 h}(g)$ & $79 \pm 7$ & $72 \pm 7$ & $56 \pm 8$ \\
\hline $\mathrm{Cl}(\mathrm{g})$ & $291 \pm 9^{a}$ & $280 \pm 9^{a b}$ & $257 \pm 10^{b}$ \\
\hline $\mathrm{Cl}_{\mathrm{BW}}(\% \mathrm{BW})$ & $22.68 \pm 0.72^{a}$ & $21.87 \pm 0.68^{a b}$ & $19.82 \pm 0.77^{b}$ \\
\hline$W_{72 h}(g)$ & $1743 \pm 39$ & $1712 \pm 38$ & $1745 \pm 42$ \\
\hline$W G_{72 h}(g)$ & $396 \pm 16$ & $386 \pm 14$ & $393 \pm 18$ \\
\hline WW (g) & $5645 \pm 128$ & $5555 \pm 130$ & $5672 \pm 150$ \\
\hline$W G_{w}(g)$ & $4297 \pm 110$ & $4231 \pm 114$ & $4310 \pm 133$ \\
\hline $\operatorname{MR}(\%)^{*}$ & $4.67 \pm 1.73$ & $4.17 \pm 1.67$ & $9.57 \pm 3.05$ \\
\hline
\end{tabular}

Note. 'BiW = birth weight; $\mathrm{W} 24 \mathrm{~h}=$ weight at 24 hours; $\mathrm{WG}_{24 \mathrm{~h}}$ weight gain up to 24 hours after birth; $\mathrm{Cl}$ = colostrum intake; $\mathrm{Cl}_{\mathrm{BW}}=$ colostrum intake relative to body weight; $\mathrm{W} 72 \mathrm{~h}=$ weight at 72 hours; $\mathrm{WG}_{72 \mathrm{~h}}$ : weight gain up to 72 hours after birth; $W W=$ weaning weight; $W_{W}=$ weight gain from birth to weaning; $\mathrm{MR}=$ mortality rate. *Analysed by the non-parametric Kruskal-Wallis test, with $p=0.1686$. Means followed by different lowercase letters in the same row differed by the Tukey-Kramer test $(p<0.05)$. 
Results related to $\mathrm{BO}$ indicated that this factor did not interfere with colostrum intake in piglets born up to $\mathrm{BO} 12$; however, piglets with $\mathrm{BO} \geq 13$ had restricted colostrum intake (Table 4). Considering that 12 hours after birth the litters of all sows were equalised, and that each litter consisted of 16 piglets, on average, about 4 piglets per litter (25\%) had restricted colostrum intake. This result explains, at least partially, the high MR registered in piglets with $B O \geq 13$. Although the MR did not differ statistically between groups, it was approximately 2.2 times higher in piglets with $B O \geq 13$ in comparison to the other piglets. These results do not corroborate those of other studies indicating that piglets born later were not at a disadvantage with respect to colostrum intake in comparison to piglets born earlier during the parturition process ${ }^{(11,27,31,32)}$. Le Dividich et al. ${ }^{(33)}$ reported that, at the time of birth of the last piglets, the first-born piglets were already satiated, thus being less active. In this way, there was a possibility for the latter to breastfeed, as there was less competition. When the sows have more piglets than the number of available teats, there is a rotation between them in the mammary system, allowing everyone to ingest quantities above the minimum necessary ${ }^{(4)}$, with the advantage that, when these piglets are kept with their biological models, they receive cell-mediated immunity.

Except for $\mathrm{Cl}_{\mathrm{BW}}$ (which was influenced by the interaction between uniformization management and BiW) and MR, there was an effect of BiW $(p<0.05)$ on all performance variables (Table 2). Overall, the performance of piglets increased in response to the increase in BiW (Table 5). It is worth noting that there was similarity $(p>0.05)$ between the medium and heavy groups with respect to important variables, such as $\mathrm{Cl}$ and $\mathrm{WG}_{\mathrm{W}^{\prime}}$ suggesting that BiW $\geq 1,330 \mathrm{~g}$ (which corresponded to the lowest limit of the medium group) provided better balance of colostrum intake between piglets, as well as better performance in the maternity phase.

Low $\mathrm{Cl}$ associated with low BiW was also observed in the work conducted by Ferrari et al. ${ }^{(34)}$, a result that is in line what was previously mentioned regarding the impairment of colostrum intake. León ${ }^{(31)}$ also studied the technique of split suckling, based on BiW, with respect to the behaviour and colostrum intake in newborn piglets. This author observed that, regardless of the treatments to which the litters were submitted, heavy piglets had higher colostrum intake than light piglets. In that study, it was also observed that the light piglets submitted to split suckling had ingested less colostrum than in the UNIF group, a fact considered by the author as a stressful effect of this type of management.

There was interaction $(p<0.05)$ between uniformization management and BiW with respect to the $\mathrm{Cl}_{B W}$ (Table 2). In the very light group, it was found that piglets from the UNIF treatment had higher $\mathrm{Cl}_{\mathrm{BW}}$ than the piglets from the BIOM treatment (27.48 vs. 23.01\% BW; Table 6). In the UNIF treatment, the very light group had higher $\mathrm{Cl}_{\mathrm{BW}}$ than the other BiW groups, which did not differ from each other (mean of $20.43 \% \mathrm{BW}$ ). In the BIOM treatment, the heavy group had lower $\mathrm{Cl}_{\mathrm{BW}}(16.82 \% \mathrm{BW})$ than the other BiW groups, which did not differ from each other (mean of $22.82 \% \mathrm{BW}$ ). There was interaction $(p<0.05)$ between uniformization management and BiW with respect to the $\mathrm{Cl}_{\mathrm{BW}}$ (Table 2). In the very light group, it was found that piglets from the UNIF treatment had higher $\mathrm{Cl}_{\mathrm{BW}}$ than the piglets from the BIOM treatment (27.48 vs. 23.01\% BW; Table 6). In the UNIF treatment, the very light group had higher $\mathrm{Cl}_{\mathrm{BW}}$ than the other BiW groups, which 
did not differ from each other (mean of $20.43 \%$ BW). In the BIOM treatment, the heavy group had lower $\mathrm{Cl}_{\mathrm{BW}}(16.82 \% \mathrm{BW})$ than the other BiW groups, which did not differ from each other (mean of $22.82 \%$ BW).

Table 5. Means and standard errors for performance traits and mortality rate of piglets in the birth weight groups during the maternity phase.

\begin{tabular}{|c|c|c|c|c|}
\hline \multirow{2}{*}{ Variable' } & \multicolumn{4}{|c|}{ Birth weight } \\
\hline & Very light & Light & Medium & Heavy \\
\hline $\operatorname{BiW}(g)$ & $891 \pm 15^{d}$ & $1204 \pm 7^{c}$ & $1440 \pm 6^{b}$ & $1775 \pm 16^{a}$ \\
\hline W24h (g) & $944 \pm 18^{d}$ & $1277 \pm 14^{c}$ & $1531 \pm 9^{b}$ & $1843 \pm 18^{a}$ \\
\hline$W G_{24 h}(g)$ & $52 \pm 6^{b}$ & $73 \pm 11^{a b}$ & $90 \pm 8^{a}$ & $70 \pm 9^{a b}$ \\
\hline $\mathrm{Cl}(\mathrm{g})$ & $224 \pm 8^{b}$ & $269 \pm 13^{b}$ & $312 \pm 10^{a}$ & $310 \pm 12^{a}$ \\
\hline $\mathrm{Cl}_{\mathrm{BW}}(\% \mathrm{BW})$ & $25.10 \pm 0.83$ & $22.27 \pm 1.03$ & $21.74 \pm 0.69$ & $17.61 \pm 0.68$ \\
\hline W72h (g) & $1197 \pm 23^{d}$ & $1584 \pm 22^{c}$ & $1878 \pm 18^{b}$ & $2234 \pm 23^{a}$ \\
\hline$W_{72 h}(g)$ & $288 \pm 13^{c}$ & $378 \pm 19^{b}$ & $438 \pm 17^{a}$ & $457 \pm 17^{a}$ \\
\hline WW (g) & $4413 \pm 135^{d}$ & $5158 \pm 120^{c}$ & $6070 \pm 104^{b}$ & $6719 \pm 131^{a}$ \\
\hline$W_{W}(g)$ & $3494 \pm 130^{c}$ & $3951 \pm 119^{b}$ & $4631 \pm 103^{a}$ & $4940 \pm 131^{a}$ \\
\hline $\operatorname{MR}(\%)^{*}$ & $8.33 \pm 2.67$ & $7.69 \pm 3.04$ & $1.96 \pm 1.38$ & $5.00 \pm 2.19$ \\
\hline
\end{tabular}

Note. 'BW = birth weight; $\mathrm{W} 24 \mathrm{~h}=$ weight at 24 hours; $\mathrm{WG}_{24 \mathrm{~h}}=$ weight gain up to 24 hours after birth; $\mathrm{Cl}=$ colostrum intake; $\mathrm{Cl}_{\mathrm{BW}}=$ colostrum intake relative to body weight; $\mathrm{W} 72 \mathrm{~h}=$ weight at 72 hours; $W_{72 h}=$ weight gain up to 72 hours after birth; $W W$ = weaning weight; $W G W$ = weight gain from birth to weaning; $\mathrm{MR}=$ mortality rate.

*Analysed by the non-parametric Kruskal-Wallis test, with $p=0.1931$.

Means followed by different lowercase letters in the same row differed by the Tukey-Kramer test ( $p$ $<0.05)$.

Table 6. Means and standard errors for colostrum intake relative to body weight in response to the interaction between the uniformization management and birth weight groups.

\begin{tabular}{|c|c|c|c|}
\hline \multirow{2}{*}{ Variable' } & \multirow{2}{*}{ Birth weight } & \multicolumn{2}{|c|}{ Uniformization" } \\
\hline & & UNIF & BIOM \\
\hline \multirow{4}{*}{$\mathrm{Cl}_{\mathrm{BW}}(\% \mathrm{BW})$} & Very light & $27.48 \pm 1.05^{\mathrm{Aa}}$ & $23.01 \pm 1.19^{\mathrm{Ba}}$ \\
\hline & Light & $21.50 \pm 1.34^{\mathrm{Ab}}$ & $23.05 \pm 1.57^{\mathrm{Aa}}$ \\
\hline & Medium & $21.06 \pm 0.89^{A b}$ & $22.39 \pm 1.06^{\mathrm{Aa}}$ \\
\hline & Heavy & $18.73 \pm 0.97^{\mathrm{Ab}}$ & $16.82 \pm 0.93^{\mathrm{Ab}}$ \\
\hline
\end{tabular}

Note. ${ }^{\prime} \mathrm{Cl}_{\mathrm{BW}}=$ colostrum intake relative to body weight.

"UNIF = uniformization between different litters; $\mathrm{BIOM}=$ permanence with the biological mothers.

Uppercase letters in the same row and lowercase letters in the same column indicate the comparison of means by Tukey-Kramer test $(p<0.05)$.

The $\mathrm{Cl}_{\mathrm{BW}}$ is an important variable, as there is a physiological limit for colostrum intake. Therefore, regardless of the management used, the tendency is that intake will be proportional to weight. Colostrum intake depends both on the sows' ability to produce enough colostrum amount for the entire litter, and on the piglets' ability to reach the teats and suckle. It is known that this action is influenced by the BiW, piglets' vitality 
at birth, and litter characteristics $(4,8,11,12,26,33)$. Since the amount of colostrum ingested is highly variable among piglets ${ }^{(11)}$, colostrum intake is expected to be lower in piglets with low BiW. However, in the present study, an inverse relationship was found. The $\mathrm{Cl}_{\mathrm{BW}}$ of very light piglets was $34.5 \%$ higher than that of light to heavy piglets in the UNIF treatment, and $36.8 \%$ higher than that of heavy piglets in the BIOM treatment (Table 6). Thus, management practices that seek to improve the colostrum intake of light piglets are apparently unnecessary, because these piglets suckle more colostrum in proportion to their weight. In the overall mean of the present study, BiW was $1,326 \mathrm{~g}$ and $\mathrm{Cl}$ was $279 \mathrm{~g}$, resulting in $\mathrm{Cl}_{\mathrm{BW}}$ of $21.69 \% \mathrm{BW}$.

The assessment of the effect of BiW groups on $\mathrm{Cl}_{\mathrm{BW}}$ in each uniformization treatment (Table 6) indicated that very light piglets equalised soon after birth ingested greater amount of colostrum in comparison to those that remained for 12 hours with their biological mothers. This result is probably due to the fact that uniformization after farrowing ensures an available teat for each piglet, which may favour piglets with low BiW. However, as the litters of the UNIF group were equalised soon after birth, many piglets ended up ingesting little colostrum from their biological mothers and, as a consequence, they lost the line of defence provided by the cellular immunity received from the mothers. Therefore, greater $\mathrm{Cl}_{\mathrm{BW}}$ by piglets with low BiW does not justify that management, as it can compromise their immunity.

Another study that supports the idea of not practicing uniformization management is that conducted by Wang et al.(35) These authors obtained results according to which colostrum intake had only partially improved the inferior status of the jejunal mucosa in intrauterine growth-retarded newborns. Also, Declerck et al.(36) concluded that piglets born last in the birth sequence, exceeding the number of available teats, obtained less passive immunity than the piglets born first. However, those last-born piglets did not have greater risk of dying before weaning. The main causes of mortality were low BiW and insufficient colostrum intake (energy) ${ }^{(36)}$.

Since the Brazilian swine industry uses a large number of vaccines in sows to promote the passive transfer of immunity from the mothers to the piglets, any interference in colostrum management can impair the effectiveness of immunisation. The lactating mothers can regulate the microbiota early in the piglets' lives. However, it is still unclear how this fact may affect the gastrointestinal microbiota and immune status, which are essential for intestinal health in early life $\mathrm{e}^{(37)}$. In this sense, Bandrick et al.(23) demonstrated that piglets born from immunised sows and equalised before six hours after birth had not acquired cellular immunity. Furthermore, only $22 \%$ of those born from non-immunised sows and transferred before six hours after birth to immunised sows tested positive in the delayed hypersensitivity test for Mycoplasma hyopneumoniae. Loving et al. ${ }^{(29)}$ observed that, while colostral antibody is absorbed into the circulation of piglets, regardless of the sow from which they receive colostrum, the transfer of maternal cells requires colostrum from the biological mothers. In accordance with that study, Tuboly et al. ${ }^{(38)}$ observed that the absorption of colostral cells only occurred when the piglets fed from their biological mothers, which gave them cellular immunity. Maradiaga et al. ${ }^{(39)}$ demonstrated that uniformization impacted the trajectory of certain 
bacterial genera in the piglets, and that there was a strong maternal influence on the development of the piglets' microbiome. The present experiment was not intended to assess the performance of piglets in subsequent phases; however, it is expected that those kept with their biological mothers during the first 12 hours of life have better immune status in comparison to those equalised soon after birth.

\section{Conclusion}

It is possible to obtain a satisfactory piglets' performance by maintaining the litters with their biological mothers during the first twelve hours after birth. The management of litter uniformity right after birth did not improve piglets' performance. Therefore, this practice can be avoided on the farm where the present experiment was conducted. The $\mathrm{Cl}$ was lower, both on an absolute basis (g) and relative to BW (\%), in piglets of $\mathrm{BO}$ equal to or greater than 13. On the other hand, the $\mathrm{Cl}$ on an absolute basis was higher, but relative to BW it was lower in heavy piglets in comparison to light piglets.

\section{Acknowledgments}

The authors are grateful to the pig farm Granja Miotto for the partnership in conducting the experiment; and to the students and professors of the Universidade Federal do Paraná (UFPR) for their dedication in conducting the research.

\section{Conflict of interests}

The authors declare no conflict of interest.

\section{References}

1. Beaulieu AD, Aalhus JL, Williams NH, Patience JF. Impact of piglet birth weight, birth order, and litter size on subsequent growth performance, carcass quality, muscle composition, and eating quality of pork. Journal of Animal Science [Internet]. 2010 Aug [cited 2020 Dec 05]; 88(8): 2767-2778. Available from: https://doi.org/10.2527/jas.2009-2222

2. Rutherford KMD, Baxter EM, D'eath RB, Turner SP, Arnott G, Roehe R, et al. The welfare implications of large litter size in the domestic pig I: biological factors. Animal Welfare [Internet]. 2013 May [cited 2020 Dec 05]; 22(2): 199-218. Available from: https://doi. org/10.7120/09627286.22.2.199

3. Baxter EM, Rutherford KMD, D'eath RB, Arnott G, Turner SP, Sandoe P, et al. The welfare implications of large litter size in the domestic pig II: management factors. Animal Welfare [Internet]. 2013 May [cited 2020 Dec 05]; 22(2): 219-238. Available from: https://doi. org/10.7120/09627286.22.2.219

4. Quesnel H, Farmer C, Devillers N. Colostrum intake: influence on piglet performance and factors of variation. Livestock Science [Internet]. 2012 July [cited 2020 Dec 05]; 146(2-3): 105114. Available from: https://doi.org/10.1016/j.livsci.2012.03.010

5. Quiniou N, Dagorn J, Gaudré D. Variation of piglets' birth weight and consequences on 
Influência de fatores biológicos e de manejo sobre o leitão na fase de maternidade Hideshima C $S$ et al.

subsequent performance. Livestock Production Science [Internet]. 2002 Nov 28 [cited 2020 Dec 05]; 78(1): 63-70. Available from: https://doi.org/10.1016/S0301-6226(02)00181-1

6. Fix JS, Cassady JP, Herring WO, Holl JW, Cullbertson MS, See MT. Effect of piglet birth weight on body weight growth, backfat, and longissimus muscle area of commercial market swine. Livestock Science [Internet]. 2010 Jan [cited 2020 Dec 05]; 127(1): 51-59. Available from: https:// www.sciencedirect.com/science/article/abs/pii/S1871141309002996

7. Kilbride AL, Mendl M, Statham P, Held S, Harris M, Cooper S, et al. A cohort study of preweaning piglet mortality and farrowing accommodation on 112 commercial pig farms in England. Preventive Veterinary Medicine [Internet]. 2012 May [cited 2020 Dec 06]; 104(3-4): 281-291. Available from: https://doi.org/10.1016/j.prevetmed.2011.11.011

8. Rooke JA, Bland IM. The acquisition of passive immunity in the new-born piglet. Livestock Production Science [Internet]. 2002 Nov 28 [cited 2020 Dec 06]; 78(1): 13-23. Available from: https://doi.org/10.1016/S0301-6226(02)00182-3

9. Xu RJ, Wang F, Zhang SH. Postnatal adaptation of the gastrointestinal tract in neonatal pigs: a possible role of milk-borne growth factors. Livestock Production Science [Internet]. 2000 Oct [cited 2020 Dec 07]; 66(2): 95-107. Available from: https://doi.org/10.1016/S0301$\underline{6226(00) 00217-7}$

10. Klobasa F, Werhahn E, Butler JE. Composition of sow milk during lactation. Journal of Animal Science [Internet]. 1987 May [cited 2020 Dec 07]; 64(5): 1458-1466. Available from: https://doi. org/10.2527/jas1987.6451458x

11. Devillers N, Le Dividich J, Prunier A. Influence of colostrum intake on piglet survival and immunity. Animal [Internet]. 2011 [cited 2020 Dec 07]; 5(10): 1605-1612. Available from: https:// doi.org/10.1017/S175173111100067X

12. Le DividichJ. A review-neonatal and weaner pig: management to reduce variation. In: Cranwell PD, editor. Manipulating Pig Production VII: proceedings of the Seventh Biennial Conference of the Australasian Pig Science Association-Apsa [Internet]. Adelaide (AU): Australian Pig Science Association; 1999 [cited 2020 Dec 07]. v. 7, p. 135-155. Available from: https://hal.inrae.fr/hal$\underline{02771776}$

13. Cutler RS, Fahy VA, Spicer EM, Cronin GM. Pre-weaning mortality. In: Straw BE, D'allaire S, Mengeling WL, Taylor DJ. Diseases of swine. 8nd ed. Ames (IA): Iowa State University Press; 1999. 985-1002.

14. Huting AMS, Almond K, Wellock I, Kyriazakis I. What is good for small piglets might not be good for big piglets: The consequences of cross-fostering and creep feed provision on performance to slaughter. Journal of Animal Science [Internet] 2017 Nov; [cited 2021 Feb 14]; 95(11):4926-4944. Available from: https://doi.org/10.2527/jas2017.1889

15. Bierhals T, Magnabosco D, Ribeiro RR, Perin J, da Cruz RA, Bernardi ML, et al. Influence of pig weight classification at cross-fostering on the performance on the primiparous sow and the adopted litter. Livestock Science [Internet]. 2012 July [cited 2020 Dec 08]; 146(2-3): 115-122. Available from: https://doi.org/10.1016/j.livsci.2012.02.026

16. Pajžlar, L, Skok, J. Cross-fostering into smaller or older litter makes piglets integration difficult: Suckling stability-based rationale. Applied Animal Behavior Science [Internet] 2019 Aug [cited 2020 Dec 21]; 220, 104856. Available from: https://doi.org/10.1016/j.applanim.2019.104856

17. Zhang, X.; Wang, M.; He, T.; Long, S.; Guo, Y.; Chen, Z. Effect of different cross-fostering 
Influência de fatores biológicos e de manejo sobre o leitão na fase de maternidade Hideshima C S et al.

strategies on growth performance, stress status and immunoglobulin of piglets. Animals [Internet] 2021 Feb; 11 (2), 499. Available from: https://doi.org/10.3390/ani11020499

18. Neal MS, Irvin KM. The effects of crossfostering pigs on survival and growth. Journal of Animal Science [Internet]. 1991 Jan [cited 2020 Dec 08]; 69(1): 41-46. Available from: https://doi. org/10.2527/1991.69141x

19. Straw BE, Dewey CE, Burgi EJ. Patterns of crossfostering and piglets mortality on commercial U.S. and Canadian swine farms. Preventive Veterinary Medicine [Internet]. 1998 Jan [cited 2020 Dec 08]; 33(1-4): 83-89. Available from: https://doi.org/10.1016/S0167-5877(97)00051-2

20. Robert S, Martineau GP. Effects of repeated cross-fostering on preweaning behavior and growth performance of piglets and on maternal behavior of sows. Journal of Animal Science [Internet]. 2001 Jan [cited 2020 Dec 08]; 79(1): 88-93. Available from: https://doi. org/10.2527/2001.79188x

21. Calderón Díaz JA, García Manzanilla E, Diana A, Boyle LA. Cross-fostering implications for pig mortality, welfare and performance. Frontiers in Veterinary Science [Internet] 2018 Jun 6 [cited 2021 Feb 14]; 5:123. Available from: https://doi.org/10.3389/fvets.2018.00123

22. Mores N, Sobestiansky J, Wentz I, Moreno AM. Manejo do leitão desde o nascimento até o abate. In: Mores N, Sobestiansky J, Wentz I, Moreno AM, editors. Suinocultura intensiva: produção, manejo e saúde do rebanho. [Internet]. Brasília (DF): Embrapa/Serviço de Produção de Informação-SPI; Concórdia (SC): Embrapa/Centro Nacional de Pesquisa de Suínos e AvesCNPSA; 1998 [cited 2020 Dec 08]. p. 135-162. Available from: https://www.bdpa.cnptia.embrapa. br/consulta/busca?b=ad\&id=434884\&biblioteca=vazio\&busca=autoria:\%22MOREN0,\%20

A.\%22\&qFacets=autoria:\%22MORENO,\%20A.\%22\&sort=\&paginacao=t\&paginaAtual=1.

Portuguese.

23. Bandrick M, Pieters M, Pijoan C, Molitor T. W. Passive transfer of maternal Mycoplasma hyopneumoniae-specific cellular immunity to piglets. Clinical and Vaccine Immunology [Internet]. 2008 Mar [cited 2020 Dec 08]; 15(3): 540-543. Available from: https://doi.10.1128/ CVI.00466-07

24. Williams PP. Immunomodulating effects of intestinal absorbed maternal colostral leukocytes by neonatal pigs. Canadian Journal of Veterinary Research [Internet]. 1993 Jan [cited 2020 Dec 09]; 57(1): 1-8. Available from: https://www.ncbi.nlm.nih.gov/pmc/articles/PMC1263580

25. Beyer M, Jentsch W, Kuhla S, Wittenburg H, Kreienbring F, Scholze $H$, et al. Effects of dietary energy intake during gestation and lactation on milk yield and composition of first, second and fourth parity sows. Archives of Animal Nutrition [Internet]. 2007 Nov [cited 2020 Dec 09]; 61(6): 452-468. Available from: https://doi.org/10.1080/17450390701563433

26. Devillers N, Van Milgen J, Prunier A, Le Dividich J. Estimation of colostrum intake in the neonatal pig. Animal Science [Internet]. 2004 Apr [cited 2020 Dec 09]; 78(2): 305-313. Available from: https://doi.org/10.1017/S1357729800054096

27. Devillers N, Farmer C, Le Dividich J, Prunier A. Variability of colostrum yield and colostrum intake in pigs. Animal [Internet]. 2007 [cited 2020 Dec 05]; 1(7): 1033-1041. Available from: https://doi.org/10.1017/S175173110700016X

28. SAS - Statistical Analysis System (2002). SAS user's guide: statistics, version 9.0. Cary: SAS Institute.

29. Loving CL, Brockmeier SL, Vincent AL, Gauger PC, Zanella EL, Lager KM, et al. Cross-fostering 
Influência de fatores biológicos e de manejo sobre o leitão na fase de maternidade Hideshima C S et al.

to prevent maternal cell transfer did not prevent vaccine-associated enhanced respiratory disease that occurred following heterologous influenza challenge of pigs vaccinated in the presence of maternal immunity. Viral Immunology [Internet]. 2014 Sept [cited 2020 Dec 06]; 27(7): 334-342. Available from: https://doi.org/10.1089/vim.2014.0034

30. Picone G, Zappaterra M, Luise D, Trimigno A, Capozzi F, Motta V, Davoli R, Nanni Costa L, Bosi $P$, Trevisi P. Metabolomics characterization of colostrum in three sow breeds and its influences on piglets' survival and litter growth rates. Journal of Animal Science and Biotechnology [Internet]. 2018 Mar [cited 2020 Oct 12]; 20(1): 75-85. Available from: https://doi.org/10.1186/ s40104-018-0237-1

31. León MY. Efeito da amamentação parcelada sobre o comportamento e a ingestão de colostro em leitões recém-nascidos (master's thesis on the Internet]. Palotina (PR): Programa de Pós-Graduação em Ciência Animal, Universidade Federal do Paraná, Setor Palotina; 2018 [cited 2020 Dec 10]. 85 p. Available from: https://acervodigital.ufpr.br/handle/1884/57036

32. Fraser D, Rushen J. Colostrum intake by newborn piglets. Canadian Journal of Animal Science [Internet]. 1992 Mar [cited 2020 Dec 10]; 72(1): 1-13. Available from: https://cdnsciencepub. com/doi/pdf/10.4141/cjas92-001.

33. Le Dividich J, Charneca R, Thomas F. Relationship between birth order, birth weight, colostrum intake, acquisition of passive immunity and pre-weaning mortality of piglets. Spanish Journal of Agricultural Research [Internet]. 2017 June [cited 2020 Dec 09];15(2): 1-10. Available from: https://doi.org/10.5424/sjar/2017152-9921

34. Ferrari CV, Sbardella PE, Bernardi ML, Coutinho ML, Vaz Jr. IS, Wentz I, et al. Effect of birth weight and colostrum intake on mortality and performance of piglets after cross-fostering in sows of different parities. Preventive Veterinary Medicine [Internet]. 2014 June 1 [cited 2020 Dec 10]; 114(3-4): 259-266. Available from: https://doi.org/10.1016/j.prevetmed.2014.02.013

35. Wang X, Zhu Y, Feng C, Lin G, Wu G, Li D, Wang J. Innate differences and colostrum-induced alterations of jejunal mucosal proteins in piglets with intra-uterine growth restriction. British Journal of Nutrition [Internet]. 2018 Apr[citec 2021Feb 08] 119(7):734-747. Available from: https://doi.org/10.1017/S0007114518000375

36. Declerck I, Sarrazin S, Dewulf J, Maes D. Sow and piglet factors determining variation of colostrum intake between and within litters. Animal [Internet]. 2017 Aug [cited 2021 Jan 07] ;11(8):1336-1343. Available from: https://doi.org/10.1017/S1751731117000131

37. Mu C, Bian G, Su Y, Zhu W. Differential effects of breed and nursing on early-life colonic microbiota and immune status as revealed in a cross-fostering piglet model. Applied Environmental Microbiology [Internet]. 2019 Apr 18 [cited 2021 Feb 03];85(9):e02510-18. Available from: https://doi.org/10.1128/AEM.02510-18

38. Tuboly S, Bernáth S, Glávits R, Medveczky I. Intestinal absorption of colostral lymphoid cells in newborn piglets. Veterinary Immunology and Immunopathology [Internet]. 1988 Dec [cited 2020 Dec 08]; 20(1): 75-85. Available from: https://doi.org/10.1016/0165-2427(88)90027-X

39. Maradiaga, N. , Aldridge, B. , Zeineldin, M. , \& Lowe, J. (2018). Gastrointestinal microbiota and mucosal immune gene expression in neonatal pigs reared in a cross-fostering model. Microbial Pathogenesis [Internet] 2018 Aug [cited 2021 Feb 03] ;121:27-39. Available from: https://doi.org/10.1016/j.micpath.2018.05.007 